peoples of Europe" imply a federal state? Federalists say that it does, their opponents otherwise.

And what is to be made of the disjunction between the treaty's declaration that "a common foreign and security policy is hereby established" and the exceedingly tentative arrangements for reaching such a state of grace spelled out in later paragraphs? The declaration is meant to please the enthusiasts, of course, while the recitation of what is not yet possible should comfort the sceptics. Europe's failure even to form a common view of the tragedy of Yugoslavia shows that the sceptics, for the time being, are on safe ground.

In an ideal world, the future of European collaboration would not have been allowed to hang in this way on the future of such a tawdry treaty. It would have helped if the drafters had given themselves more time, or if their political masters had been able to spend more than four days at Maastricht last year. It would have been even better if all concerned had given serious thought to questions entirely overlooked in the treaty - how to avoid misunderstandings between Eurocrats and their electorates (typified by the row about the treaty itself), the balance to be struck between the rush (now postponed) for economic growth and geographical enlargement and economic relations with the larger outside world, both prosperous and poor. But the world is not ideal. Maastricht may be a poor treaty, but it is the only one on offer. Its supporters are right to say that, if it fails, it will not be easy to prevent the dissipation of the momentum that has so far successfully sustained the closer collaboration of a dozen European states.

The British government, by rotation now the holder of the presidency of Europe, is plainly hoping that the summit meeting at Edinburgh next month will help a little to that end. If it proves possible to hammer out an understanding with Denmark that might survive a second referendum, might not the same compromise also placate its own sceptics? But that is a poor way of doing serious international business. It would be better simply to renegotiate Maastricht. People in other walks of life often make mistakes, acknowledge them as such and then make them good. Are not politicians at least as vulnerable? And it would be a great misfortune to let Europe fall apart simply because statesmen are unwilling to confess that they signed a piece of paper that does not represent their intentions.

\section{Clinton on science}

\section{The election of Bill Clinton as US president is good news for fetal tissue research and for AIDS.}

Although it is too early to say with any certainty what US President-elect Bill Clinton will do about science policy in general (see page 95), his election clearly augurs a change in policy on the use of fetal tissue in human research. With a stroke of the pen, Clinton can rescind the Bush administration's ban on fetal tissue studies and he is expected to do just that within days of taking office. It will be a good decision.

The Bush administration's objections are grounded in the belief (for which there is no evidence) that clinical research with fetal tissue will encourage women to have abortions. A presidentially appointed panel of scientists and philosophers that included Bernadine Healy, the Republican director of the National Institutes of Health (NIH), concluded two years ago that, with the proper safeguards, fetal tissue research should receive federal support. Ironically, it is the Democrat Clinton who is poised to accept the advice of the Bush panel.

Clinton is also expected to recognize AIDS research in a way the Bush White House never has, with the appointment of a so-called "AIDS tsar" to coordinate research throughout the government--including the NIH, the Centers for Disease Control and the Department of Defense which has concentrated most of its AIDS funds in the US Army. Although the US government is spending $\$ 2$ billion on AIDS research, continuing complaints that the effort lacks unified direction have merit. If Clinton names an AIDS tsar (and he should), he should locate the office somewhere in the White House rather than in one of the departments of government. Further, he should select someone with the appropriate scientific knowledge but who is not running an active research laboratory. Credibility and independence require that a White House AIDS coordinator should not compete for funds or credit with those labouring in the laboratory.

\section{Telephone roundabouts}

Cellular telephony seems likely to turn the US telecommunications business upside down.

TECHNOLOGY has a nasty habit of making a monkey of the best laid plans. That is what may be happening to the careful arrangements made in the United States to break up the telephone monopoly known as the Bell System. For five years, federal Judge Harold Green laboured to create some semblance of competition from pieces of the holding company, known as AT\&T. His solution, in 1984, seemed sensible enough. The Bell System would be broken up while a company called AT\&T would continue to exist to provide long distance and international communications services in competition with then newly licensed companies with names such as MCI and Sprint. Judge Green, believing that the physical ownership of telephone networks gave the baby Bells a de facto monopoly, clipped their wings by denying them long-distance business.

That was eight years ago. Now, guess what? AT\&T seems to be well placed to recover its old position as the major telephone provider. Last week, Wall Street was in a whirl when told that AT\&T plans to buy more than a third of a company called McCaw, which provides cellular telephone services in the United States. McCaw seems to have acquired its 2 million subscribers in the interval since Judge Green's consent decree, and with the help of a technology he had not foreseen. With AT\&T's help, it will probably now grow even faster, skimming the cream from the baby Bells to share it with AT\&T. The moral? There is none, unless it is that people who expect technology to stand still expect too much. 